\title{
Studi Optimasi Parameter Daya RF untuk Penumbuhan Lapisan Tipis Mikrokristal Silikon dengan Metode Hot Wire Cell PECVD
}

\author{
S. Amiruddin ${ }^{1)}$, I. Usman ${ }^{2)}$, Mursal $^{3)}$, T. Winata ${ }^{4)}$ \& Sukirno ${ }^{4)}$ \\ ${ }^{1)}$ Prodi Fisika, Jurusan PMIPA, FKIP, Universitas Nusa Cendana, Kupang \\ ${ }^{2)}$ Jurusan Fisika, FPMIPA, Universitas Haluoleo, Kendari \\ ${ }^{3)}$ Jurusan Fisika, FPMIPA, Universitas Syiah Kuala, Aceh \\ ${ }^{4)}$ Laboratorium Fismatel, Departemen Fisika, FMIPA, Institut Teknologi Bandung \\ E-mail:amirsupu@dosen.fisika.net
}

\begin{abstract}
Abstrak. Metode Hot Wire Cell PECVD (Plasma Enhanced Chemical Vapor Deposition) telah berhasil dikembangkan untuk menumbuhkan lapisan tipis amorf silikon terhidrogenasi (a-Si:H) dengan konduktivitas yang relatif tinggi. Lapisan tipis a-Si:H ditumbuhkan di atas gelas corning 7059 pada temperatur filamen $800{ }^{\circ} \mathrm{C}$. Gas silan $\left(\mathrm{SiH}_{4}\right) \quad 10 \%$ dalam gas hidrogen $\left(\mathrm{H}_{2}\right)$ digunakan sebagai sumber gas. Dalam metode hot wire cell PECVD, gas reaktan didekomposisi dengan filamen tungsten panas yang diletakkan diluar kedua elektroda dan paralel dengan system gas masukan. Dari hasil karakterisasi diperoleh bahwa laju deposisi meningkat dari $0,89 \AA /$ s sampai $1,90 \AA /$ s dengan meningkatnya daya rf dari 60 watt sampai 120 watt. Celah pita optik menurun dari 1,68 eV sampai 1,56 eV dengan meningkatnya daya rf dari 60 watt sampai 120 watt. Dari hasil foto SEM dan spektrum XRD memperlihatkan adanya transisi amorf ke mikrokristal pada daya rf 120 watt. Transisi amorf ke mikrokristal ditandai dengan berkurangnya fasa amorf dan adanya puncak difraksi pada orientasi kristal istimewa $<111>$. Konduktivitas gelap dan terang lapisan tipis $\mu \mathrm{c}-\mathrm{Si}: \mathrm{H}$ yang diperoleh sebesar $6,84 \times 10^{-6} \mathrm{~S} \mathrm{~cm}^{-1}$ dan $4,16 \times 10^{-4} \mathrm{~S}$ $\mathrm{cm}^{-1}$.
\end{abstract}

Kata Kunci: a-Si:H; Hot Wire Cell PECVD; Konduktivitas; $\mu$-Si:H; dan Orientasi kristal.

Abstract. The Hot Wire Cell PECVD method has been developed and
successfully applied to grow the hydrogenated amorphous silicon (a-Si:H) thin
films with a relatively high conductivity. The a-Si:H thin films were grown on
the 7059 corning glass at a filament temperature of $800{ }^{\circ} \mathrm{C}$. Ten percents silane
$\left(\mathrm{SiH}_{4}\right)$ gas diluted in hydrogen $\left(\mathrm{H}_{2}\right)$ gas was used as gas source. In the hot wire
cell PECVD method, reactant gases are decomposed as a result of reaction with a
heated filament. The filament was placed parallelly with inlet gas system and
outside of electrodes. The characterization results exhibited that the deposition
rate increased from $1.02 \AA / \mathrm{s}$ to $1.90 \AA$ / $/ \mathrm{s}$ with increasing the rf power from 80
watt to 120 watt. The optical bandgap decreased from $1.65 \mathrm{eV}$ to $1.56 \mathrm{eV}$ with
increasing the rf power from 80 watt to 120 watt. The SEM image and the XRD 
spectrum exhibited the transition of amorphous to microcrystalline silicon at an rf power of 120 watt. The transition of amorphous to microcrystalline was indicated by the reduction of amorphous parts and the appearance of peak diffraction at $<111>$ preferential crystal orientation. The dark and photo conductivities of the obtained $\mu \mathrm{c}-\mathrm{Si}: \mathrm{H}$ thin films was $6.84 \times 10^{-6} \mathrm{~S} \mathrm{~cm}^{-1}$ and $4.16 \times 10^{-4} \mathrm{~S} \mathrm{~cm}^{-1}$, respectively.

Keywords: a-Si:H; Conductivity; Crystal orientation; Hot Wire Cell PECVD; and $\mu c-S i: H$.

\section{Pendahuluan}

Lapisan tipis silikon amorf terhidrogenasi (a-Si:H) dapat dideposisi dengan beberapa teknik, seperti $r f$ dan $d c$ glow discharge, photo-CVD, ion-cluster beam dan sputtering. Radio frequency (rf) glow discharge dan photo-CVD merupakan teknik deposisi lapisan tipis a-Si:H yang umum digunakan dengan kualitas lapisan yang tinggi [1]. Sistem deposisi plasma untuk menumbuhkan material silikon amorf pertama kali dikembangkan oleh Chittick et.al. dengan menggunakan sistem rf induktif, dimana plasma terjadi akibat adanya induksi kumparan. Dalam pengembangan reaktor selanjutnya, digunakan konfigurasi dioda, dimana plasma terbentuk diantara dua elektroda sejajar. Sistem reaktor seperti ini disebut Plasma Enhanced Chemical Vapor Deposition (PECVD) atau Glow Discharge. Frekuensi rf yang digunakan adalah 13,56 MHz.

Dalam proses deposisi, teknik PECVD melibatkan beberapa parameter yang mempengaruhi distribusi hidrogen dalam lapisan yang dipandang sebagai faktor yang menyebabkan terjadinya degradasi sifat listrik lapisan tipis a-Si:H [2]. Selain itu, beberapa reaksi fasa gas memungkinkan terbentuknya ikatan silansilan yang tinggi dalam plasma rf, dan tumbukan dari ion-ion berenergi tinggi sehingga menambah jumlah cacat dalam lapisan. Oleh karena itu diperlukan teknik baru untuk menumbuhkan material a-Si:H dengan kandungan hidrogen yang rendah.

Teknik baru yang dikembangkan beberapa tahun terakhir ini adalah teknik Hot Wire Chemical Vapor Deposition (Hot Wire CVD), yaitu metode CVD yang dibantu dengan filamen panas [3-7]. Dengan teknik baru ini, Lapisan tipis yang dihasilkan mempunyai kualitas yang relatif lebih baik akibat dekomposisi silan pada permukaan filamen panas [8,9]. Selain itu teknik ini melibatkan parameterparameter deposisi yang relatif sedikit sehingga mudah dikontrol. Proses penumbuhan lapisan tipis melibatkan radikal-radikal sederhana yang dilepaskan dari permukaan filamen panas. 
Disamping beberapa kelebihan yang dimiliki oleh metode Hot Wire CVD seperti yang disebutkan di atas, juga terdapat beberapa kekurangan, yaitu: (1) lapisan tipis yang dihasilkan tidak memperlihatkan korelasi simetrik antara parameter-parameter deposisi dengan sifat optik dan listrik lapisan tipis yang dihasilkan; (2) lapisan tipis yang dihasilkan dengan kandungan hidrogen rendah $\left(\mathrm{C}_{\mathrm{H}}<4 \%\right)$ mempunyai konduktivitas yang relatif sama dengan lapisan tipis yang dihasilkan dengan PECVD yang kandungan hidrogennya besar $\left(\mathrm{C}_{\mathrm{H}}>15 \%\right)$; dan (3) konduktivitas lapisan tidak uniform. Wang et.al. telah meneliti sifat listrik (konduktivitas gelap) dari lapisan tipis a-Si:H yang ditumbuhkan dengan teknik Hot Wire CVD di atas substrat isolator (e.g., corning 7059 glass), diperoleh informasi bahwa untuk sampel yang sama, konduktivitas gelapnya berbeda sekitar lima orde untuk setiap lokasi yang berbeda dalam sampel. Ini menunjukkan bahwa sifat listrik lapisan tipis yang ditumbuhkan tidak uniform[10].

Untuk mengatasi kelemahan metode Hot Wire CVD, metode PECVD dikembangkan menjadi metode Hot Wire PECVD (Hot Wire Plasma Enhanced Chemical Vapor Deposition). Metode Hot Wire PECVD adalah metode PECVD yang ditambahkan filamen panas antara kedua elektroda dan berada tepat di atas substrat. Dengan metode Hot Wire PECVD, gas reaktan didekomposisi oleh filamen panas dan daya rf yang secara efektif akan meningkatkan laju dekomposisi gas reaktan. Jadi dengan metode ini diharapkan diperoleh kandungan hidrogen yang rendah dengan konduktivitas yang tinggi.

Dalam studi ini lapisan tipis a-Si:H ditumbuhkan dengan metode baru Hot Wire Cell PECVD (Hot Wire Cell Plasma Enhanced Chemical Vapor Deposition). Metode Hot Wire Cell PECVD mempunyai konfigurasi yang berbeda dari metode Hot Wire PECVD konvensional, dimana filamen diletakkan paralel dengan sistem gas masukan. Dengan menggunakan metode Hot Wire Cell PECVD transisi amorf (a-Si:H) ke mikrokristal silikon ( $\mu c-S i: H)$ diamati melalui optimasi parameter daya rf.

\section{$2 \quad$ Eksperimen}

Lapisan tipis mikrokristal silikon $(\mu \mathrm{c}-\mathrm{Si}: \mathrm{H})$ ditumbuhkan dengan metode $\mathrm{Hot}$ Wire Cell PECVD. Metode Hot Wire Cell PECVD adalah metode PECVD yang ditambahkan dengan filamen panas. Perbedaan yang signifikan antara Hot Wire Cell PECVD dengan Hot Wire PECVD konvensional terletak pada rancangan filamennya. Dalam metode Hot Wire PECVD filamen diletakkan diantara kedua elektroda dan berada tepat di atas substrat sedangkan dalam metode Hot Wire Cell PECVD, filamen diletakkan paralel dengan sistem gas masukan dan berada diluar kedua elektroda. Tungsten wire berdiameter $1,2 \mathrm{~mm}$ digunakan sebagai filamen. Filamen berupa gulungan dengan diameter $5,0 \mathrm{~mm}$ dan panjang 20 
mm, disusun paralel dengan sistem gas masukan. Jarak antara filamen dan elektroda adalah $10 \mathrm{~mm}$. Filamen dipanaskan dengan suplai daya listrik secara langsung dan dipertahankan konstan selama eksperimen berlangsung. Skema sistem Hot Wire Cell PECVD diperlihatkan pada gambar 1.

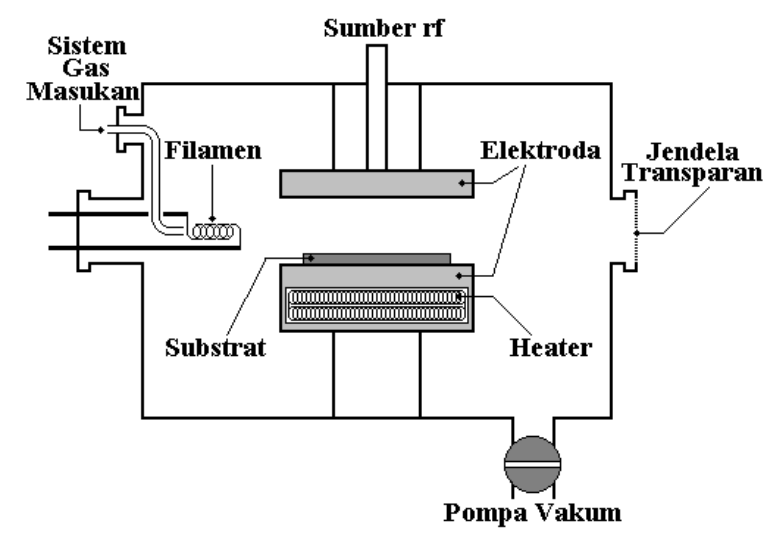

Gambar 1 Skema sistem Hot Wire Cell PECVD.

Lapisan tipis $\mu \mathrm{c}-\mathrm{Si}: \mathrm{H}$ ditumbuhkan di atas gelas corning 7059. Gas silan $\left(\mathrm{SiH}_{4}\right)$ $10 \%$ dalam gas hidrogen $\left(\mathrm{H}_{2}\right)$ digunakan sebagai sumber gas. Amiruddin et.al. ${ }^{11)}$ melaporkan bahwa dengan menggunakan metode Hot Wire Cell PECVD, lapisan tipis a-Si:H yang berkualitas baik diperoleh pada temperatur substrat $275{ }^{\circ} \mathrm{C}$, tekanan deposisi 900 mTorr, temperatur filamen $800{ }^{\circ} \mathrm{C}$ dan laju aliran gas $50 \mathrm{sccm}$. Berdasarkan hasil yang diperoleh Amiruddin et.al. di atas, parameter deposisi dalam studi ini seperti diperlihatkan dalam tabel-1.

Tabel 1 Parameter deposisi

\begin{tabular}{|l|l|}
\hline Temperatur Substrat & $275^{\circ} \mathrm{C}$ \\
\hline Daya RF & $60-120$ Watt \\
\hline Tekanan Deposisi & $900 \mathrm{mTorr}$ \\
\hline Jarak Elektroda & $2,0 \mathrm{~cm}$ \\
\hline Temperatur Filamen & $800^{\circ} \mathrm{C}$ \\
\hline Laju Aliran Gas & $50 \mathrm{sccm}$ \\
\hline
\end{tabular}

Lapisan tipis $\mu \mathrm{c}-\mathrm{Si}: \mathrm{H}$ yang telah ditumbuhkan dikarakterisasi untuk mengamati sifat optik dan listrik maupun struktur lapisannya. Spektrum Ultraviolet Visible (UV-Vis) digunakan untuk menentukan laju deposisi dan celah pita optik. X-ray diffraction (XRD) digunakan untuk menentukan fasa kristal dari lapisan. Scanning electron microscopy (SEM) digunakan untuk melihat morfologi 
permukaan. Konduktivitas diukur dengan metode dua titik (coplanar) dengan menggunakan elektrometer Keithley 617.

\section{$3 \quad$ Hasil dan Diskusi}

Laju deposisi dan celah pita optik sebagai fungsi daya rf diperlihatkan pada gambar 2. Dari gambar terlihat bahwa laju deposisi meningkat dari $0,89 \AA / \mathrm{s}$ sampai $1.90 \AA / \mathrm{s}$ dengan meningkatnya daya rf dari 60 watt sampai 120 watt. Peningkatan laju deposisi ini disebabkan oleh meningkatnya dekomposisi silan menjadi radikal-radikal sederhana. Peningkatan daya rf akan meningkatkan jumlah radikal-radikal dalam plasma yang dengan sendirinya akan meningkatkan laju difusi radikal menuju permukaan substrat. Dengan meningkatnya laju difusi radikal ke permukaan substrat maka laju deposisi juga meningkat.

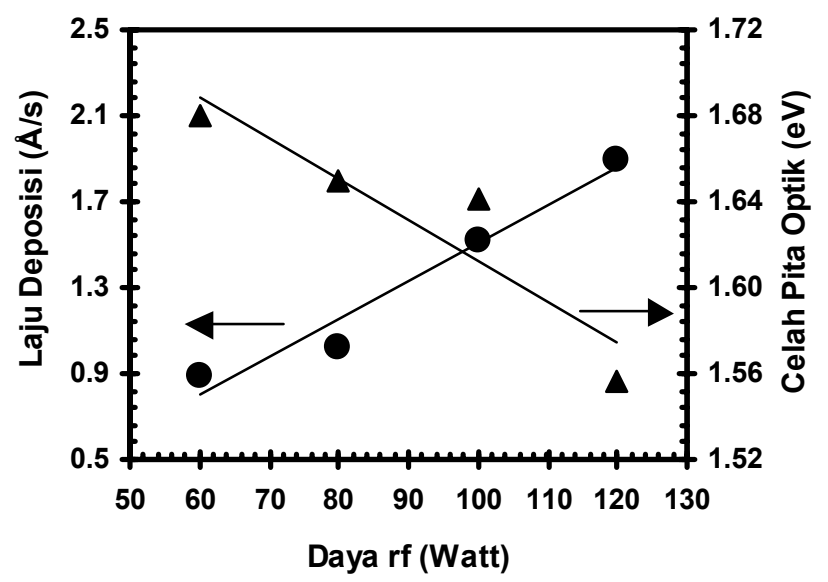

Gambar 2 Laju deposisi dan celah pita optik sebagai fungsi daya rf.

Terlihat juga bahwa celah pita optik menurun dari $1,68 \mathrm{eV}$ sampai $1,56 \mathrm{eV}$ dengan meningkatnya daya rf dari 60 watt sampai 120 watt. Penurunan celah pita optik ini disebabkan oleh menurunnya kandungan hidrogen dan bertambahnya ikatan Si-Si dalam lapisan. Dengan meningkatnya daya rf akan meningkatkan rasio radikal $\left[\mathrm{SiH}_{3}\right] /[\mathrm{H}]$ dipermukaan substrat, dimana rasio radikal $\left[\mathrm{SiH}_{3}\right] /[\mathrm{H}]$ adalah faktor yang sangat penting dalam penumbuhan lapisan tipis a-Si:H dan $\mu \mathrm{c}-\mathrm{Si}: \mathrm{H}$ yang berkualitas tinggi. Penurunan celah pita optik ini mengindikasikan adanya perubahan struktur dari amorf ke mikrokristal yang sesuai dengan hasil pengamatan dengan spektrum XRD, seperti terlihat pada gambar 3 .

Gambar 3. memperlihatkan spektrum XRD dari lapisan yang ditumbuhkan dengan menggunakan hot wire dan tanpa hot wire pada daya rf 80 watt dan 120 
watt. Dari gambar terlihat bahwa struktur lapisan dipengaruhi secara signifikan oleh daya rf. Lapisan yang ditumbuhkan baik tanpa hot wire (A) maupun dengan hot wire (B dan C) memperlihatkan adanya spektrum XRD yang lebar pada sudut 2 theta $10^{\circ}$ sampai $40^{\circ}$ yang merupakan karakteristik dari fasa amorf. Puncak intensitas spektrum lapisan yang ditumbuhkan dengan hot wire lebih rendah dari lapisan yang ditumbuhkan tanpa hot wire. Ini mengindikasikan bahwa sifat amorf dari lapisan yang ditumbuhkan dengan hot wire lebih rendah dari lapisan yang ditumbuhkan tanpa hot wire. Selain itu terlihat juga bahwa lapisan yang ditumbuhkan dengan hot wire pada daya rf 120 watt memperlihatkan adanya puncak difraksi pada sudut 2 theta $28,45^{\circ}, 47,30^{\circ}$ $56,12^{\circ}$ dan $69,14^{\circ}$ yang merupakan karakteristik dari fasa kristal. Ini berarti bahwa lapisan yang ditumbuhkan dengan hot wire pada daya rf 120 watt berstruktur mikrokristal dengan orientasi kristal $<111>,<220\rangle,<311>$ dan $<400>$. Orientasi kristal istimewa terjadi pada arah $<111>$.

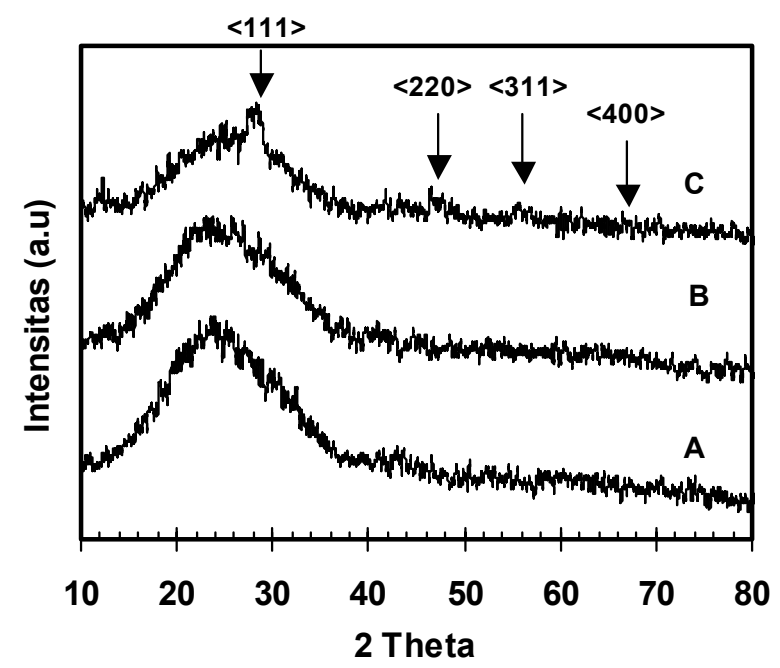

Gambar 3 Spektrum XRD lapisan tipis

(A) a-Si:H tanpa hot wire dan daya 120 watt

(B) a-Si:H dengan hot wire dan daya 80 watt

(C) $\mu \mathrm{c}-\mathrm{Si}: \mathrm{H}$ dengan hot wire dan daya 120 watt.

Gambar 4 memperlihatkan foto SEM (scanning Electron Microscopy) lapisan yang ditumbuhkan dengan hot wire pada daya 80 watt (a), 120 watt (b), dan tanpa hot wire pada daya 120 watt (c). Dari gambar terlihat bahwa terdapat perbedaan morfologi permukaan yang signifikan antara lapisan yang ditumbuhkan dengan hot wire dan yang tanpa hot wire. Lapisan yang ditumbuhkan dengan hot wire memperlihatkan adanya butiran kristal yang menunjukkan bahwa lapisan tersebut berstruktur mikrokristal. Seperti yang 
telah dijelaskan di atas, fasa lapisan berubah dari amorf ke mikrokristal dengan meningkatnya daya rf. Oleh karena itu, morfologi permukaan lapisan berubah dengan berubahnya daya rf. Lapisan yang ditumbuhkan dengan hot wire pada daya rf 120 watt memperlihatkan adanya butiran kristal yang tersebar di seluruh permukaan film.
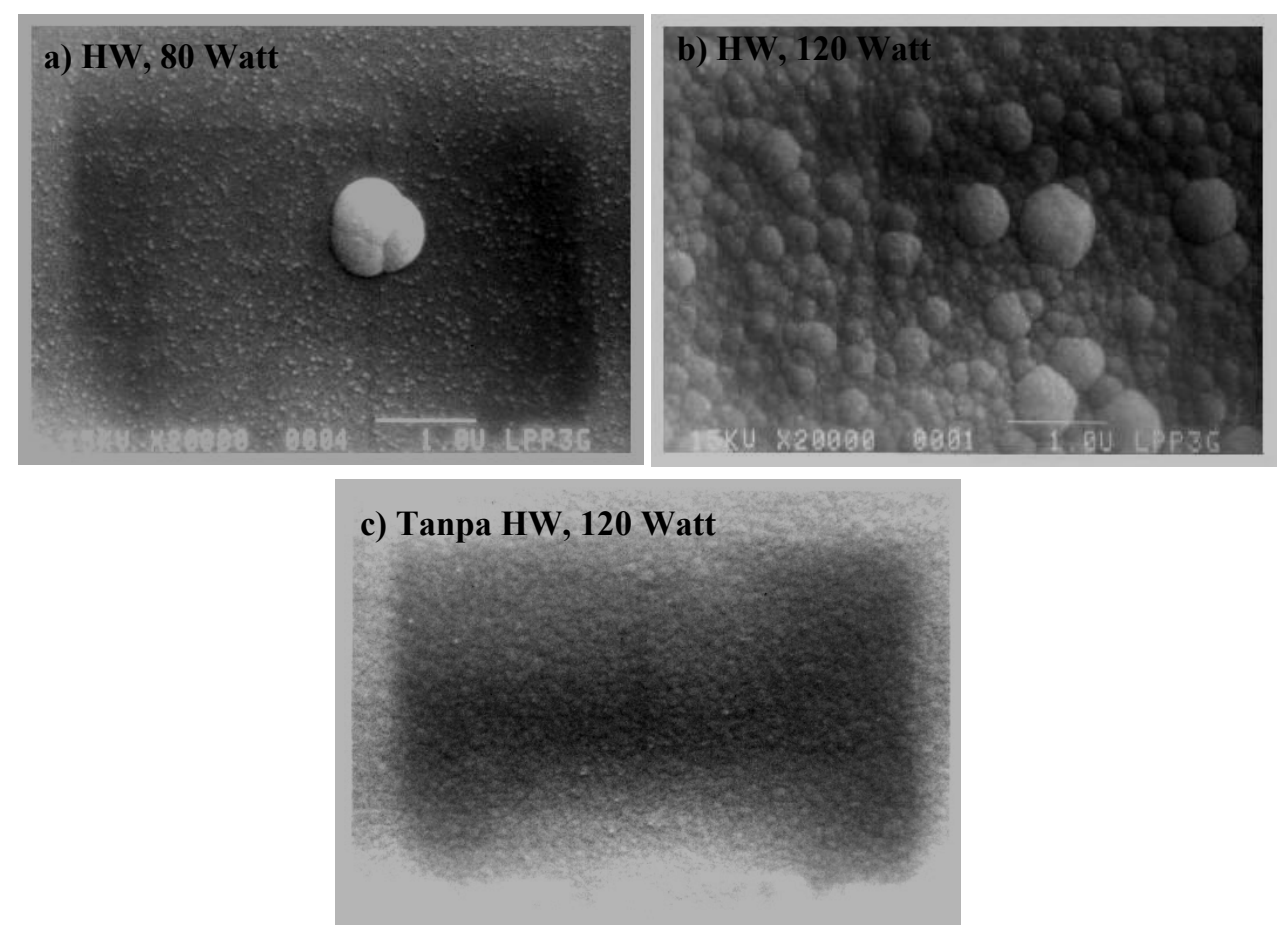

Gambar 4 Foto SEM lapisan yang dideposisi pada daya rf 80 watt (a) dan 120 watt (b) dengan hot wire serta, daya rf 120 watt tanpa hot wire (c).

Konduktivitas sebagai fungsi daya rf diperlihatkan pada gambar 5 . Konduktivitas gelap dan terang meningkat masing-masing dari $1,34 \times 10^{-7} \mathrm{~S} / \mathrm{cm}$ sampai $6,84 \times 10^{-6} \mathrm{~S} / \mathrm{cm}$ dan dari $1,88 \times 10^{-4} \mathrm{~S} / \mathrm{cm}$ sampai $4,16 \times 10^{-4} \mathrm{~S} / \mathrm{cm}$ dengan meningkatnya daya rf dari 60 watt sampai 120 watt. Peningkatan ini disebabkan oleh adanya perubahan struktur lapisan dari amorf ke mikrokristal. Konduktivitas gelap dan terang tertinggi $\left(6,84 \times 10^{-6} \mathrm{~S} / \mathrm{cm}\right.$ dan $\left.4,16 \times 10^{-4} \mathrm{~S} / \mathrm{cm}\right)$ diperoleh pada lapisan yang ditumbuhkan pada daya rf 120 watt, yaitu lapisan yang berstruktur mikrokristal, seperti yang dijelaskan pada spektrum XRD. 


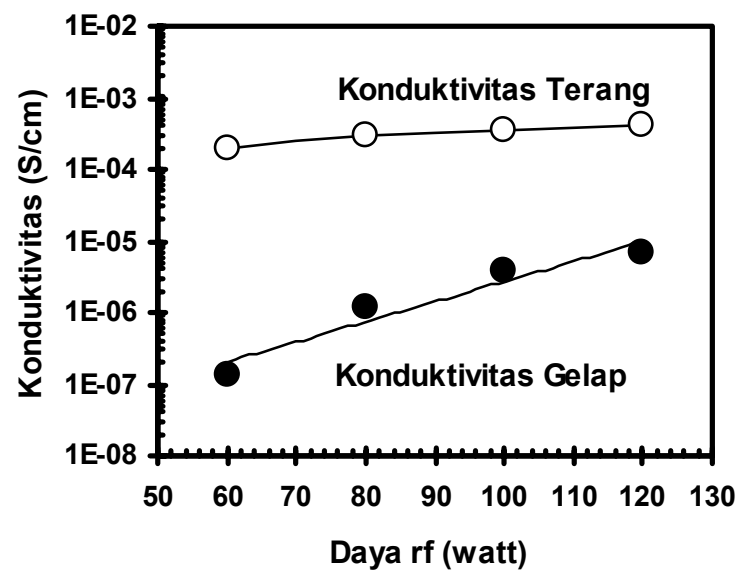

Gambar 5 Konduktivitas sebagai fungsi daya rf.

Fotosensitivitas sebagai fungsi dari daya rf diperlihatkan pada gambar 6. Dari gambar secara umum terlihat bahwa fotosensitivitas lapisan yang ditumbuhkan dengan hot wire lebih rendah dari lapisan yang ditumbuhkan tanpa hot wire. Fotosensitivitas lapisan yang ditumbuhkan dengan hot wire menurun dari $1,47 \times 10^{3}$ sampai $6,08 \times 10^{1}$ dengan meningkatnya daya rf dari 60 watt sampai 120 watt. Penurunan fotosensitivitas ini menegaskan adanya perubahan struktur dari amorf ke mikrokristal. Lapisan yang memiliki fotosensitivitas tinggi cenderung bersifat amorf, dimana fotosensitivitas yang tinggi disebabkan adanya koefisien absorpsi yang tinggi. Hal ini sesuai dengan tingginya koefisien absorpsi lapisan amorf dibandingkan dengan lapisan mikrokristal. Sedangkan fotosensitivitas lapisan yang ditumbuhkan tanpa hot wire relatif konstan.

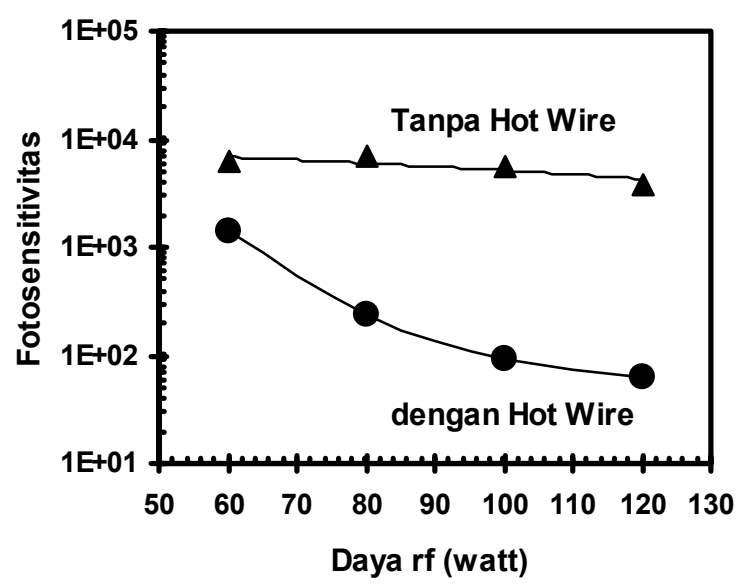

Gambar 6 Fotosensitivitas sebagai fungsi daya rf. 


\section{$4 \quad$ Kesimpulan}

Lapisan tipis $\mu \mathrm{c}-\mathrm{Si}: \mathrm{H}$ telah berhasil ditumbuhkan dengan mengoptimasi parameter daya rf menggunakan metode hot wire cell PECVD. Spektrum XRD memperlihatkan adanya perubahan struktur dari amorf ke mikrokristal pada daya 120 watt. Orientasi kristal istimewa dari lapisan tipis $\mu \mathrm{c}-\mathrm{Si}: \mathrm{H}$ terjadi pada arah $<111>$. Lapisan tipis $\mu \mathrm{c}-\mathrm{Si}: \mathrm{H}$ yang diperoleh memiliki celah pita optik dan konduktivitas gelap masing-masing $1,56 \mathrm{eV}$ dan $6,8410^{-6} \mathrm{~S} / \mathrm{cm}$ dengan laju deposisi $1.90 \AA / \mathrm{s}$. Fotosensitivitas lapisan tipis $\mu \mathrm{c}-\mathrm{Si}: \mathrm{H}\left(6,08 \times 10^{1}\right)$ lebih rendah dari fotosensitivitas lapisan tipis a-Si:H $\left(3,71 \times 10^{3}\right)$.

\section{Ucapan Terima Kasih}

Penulis mengucapkan terima kasih kepada Kementrian Riset dan Teknologi atas dana penelitiannya melalui Proyek Riset Unggulan Terpadu (RUT) VIII sehingga penelitian ini dapat terlaksana.

\section{Daftar Pustaka}

1. Street, R. A., Hydrogenated Amorphous Silicon, Cambridge University Press, London, 1991.

2. Santos P. V., Johnson N. M. \& Street R. A., Light-Enhanced Hydrogen Motion in a-Si:H, Phys. Rev. Lett., 67 pp.2686-2689, (1991).

3. Broguira, P., Conde, J. P., Arekat, S. \& Chu V., Low Filament Temperature Deposition of a-Si:H by Hot Wire Chemical Vapor Deposition, J. Appl. Phys. Vol. 78(6), p. 3776-3783 (1995).

4. Broguira, P., Conde, J. P., Arekat, S. \& Chu, V., Amorphous and Microcrystalline Silicon Films Deposited by Hot Wire Chemical Vapor Deposition at Filament Temperature Between 1500 and 1900 [degree]C, J. Appl. Phys. Vol. 79(11), p. 8748-8760 (1996).

5. Heintze, M., Zedlitz, R., Wanka, H. N. \& Scubert, M. B., Amorphous and Microcrystalline Silikon by Hot Wire Chemical Vapor Deposition, J. Apply Phys. Vol. 79(5), p.2699 - 2706 (1996).

6. Michael Hack (eds.), Amorphous Silicon Technology-1995, Material Research Society, Symposium Proceedings, Vol. 377, Pittsburgh, (1996).

7. Doyle, J., Robertson, R., Lin, G. H., He, M. Z. \& Gallagher, A., Production of High Quality Amorphous Silicon Films by Evaporative Silane Surface Decomposition, J. Appl. Phys. Vol. 64(6), p. 3215- 3223 (1988).

8. Mahan A. H. \& Vanecek M., Amer. Inst. of Phy. Conf. Proc. 234, 195, (1991).

9. Wu Y., Stephen J. T., Handayani D. X., Rutland J. M., Crandall R. S., \& A.H. Mahan, New Hydrogen Distribution in a-Si:H: An NMR Study, Phys. Rev. Lett. 77, pp.2049-2052, (1996). 
10. Wang Q., Neslon B. P., Iwaniczko E., Mahan A. H., Crandall R. S. \& Benner J., The Influence of Charge Effect on the Growth of Hydrogenated Amorphous Silicon by the Hot Wire Chemical Vapor Deposition Technique, The $2^{\text {nd }}$ World Conference and Exhibition on Photovoltaic Solar Energy Conversion, Vienna, Austria, (6-10 July 1998).

11. Amiruddin, S., Usman, I., Mursal, Winata, T., Sukirno \& Barmawi, M., Growth Study of a-Si:H Thin Films by Hot Wire Cell PECVD Method, Asian J. Energy Environ, Vol. 5(1), pp.47-58, (2004). 